\title{
Biochemical Enhancement of Geotechnical Properties of Marginal Soils
}

\author{
Murtala Hassan Mohammed ${ }^{1}$ and Ado Yusuf Abdulfatah",* \\ ${ }^{1}$ Department of Civil Engineering, Modibbo Adama University of Technology Yola, NIGERIA \\ ${ }^{2}$ Department of Civil Engineering, Bayero University, Kano, NIGERIA
}

\begin{abstract}
Microbially-induced calcite precipitation (MICP) is a relatively new and sustainable soil improvement technique. This technique utilizes bio-activity of microorganism to precipitate calcite through metabolic activities of the organisms which decompose urea in to ammonium and carbon dioxide. The carbonate so produced combined with the supplied calcium to precipitate calcite. This calcite improves engineering properties of soil through the formation of coating and bonds between soil particles. Preliminary results have proved the feasibility of the isolated bacteria in MICP treatment technique to improve the engineering properties of marginal soil. The main objective of this study is to determine the preference conditions for effective MICP treatment in improving the soil engineering properties (Unconfined Compressive Strength, California Bearing Ratio and Hydraulic Conductivity) of a typical marginal soil. Variables such as; treatment duration $(24,48$, and 72 hours $)$, reagent concentration $(0.1,0.25$, 0.5 , and $0.75 \mathrm{M})$, and concentration of the isolates $\left(1 \times 10^{5}, 1 \times 10^{6}\right.$, and $1 \times 10^{7} \mathrm{cfu} / \mathrm{ml}$ ) were considered in the MICP treatment. The results suggested that the preference treatment conditions were 72 hours treatment duration, $0.75 \mathrm{M}$ reagent concentration, and $1 \times 10^{7} \mathrm{cfu} / \mathrm{ml}$ concentration of the isolates. The corresponding alterations recorded were $94.86 \mathrm{KN} / \mathrm{m}^{2}(295 \%)$ and $30.8 \%(92.5 \%)$ increment for CBR and UCS while $0.93 \times 10^{-6} \mathrm{~m} / \mathrm{s}$ $(78.95 \%)$ reduction was recorded for hydraulic conductivity. The calcite content showed a reasonably good comparison with the improvements in the soil engineering properties. The $\mathrm{pH}$ of effluents increased during MICP treatment indicating the presence of urease bio-activity.
\end{abstract}

\section{Introduction}

Soil is one of the most commonly used construction materials, and as a result, geotechnical engineers play a vital role in a number of engineering projects, including those involving earth structures, requiring a soil or rock foundation, or those constructed below the ground surface [1]. However, unlike other materials used by engineers, soil has extremely variable physical properties. To address these challenges, a significant effort has been made over the past 300 years to improve our understanding of soil properties and its behavior [2].

\footnotetext{
*Corresponding author: ayabdulfatah.civ@buk.edu.ng
} 
Most of the efforts were being focused on improving our understanding of the relevant mechanical principles, as well as the roles of geology, chemistry, and mineralogy. Accordingly, when engineers have difficulties with on-site construction on/in soils, the conventional solutions for improving the engineering properties of the soils involve using chemical additives (e.g., Portland cement, lime, fly ash, bitumen) and/or mechanical stabilization (e.g., mixing or blending of soil and compaction) [3].

Geo-engineers have only relatively recently become aware of the potential of biological applications for improving the mechanical properties of soils [4]. This is surprising given that microbial activities are ubiquitous in surface and subsurface of soils and have a tremendous effect on the composition, properties, and behavior of soil and rock near the Earth's surface. Bacteria from various natural habitats have frequently been reported to precipitate calcium carbonate both in natural and in laboratory conditions. Different types of bacteria, as well as abiotic factors (salinity and composition of the medium) seem to contribute in a variety of ways to calcium carbonate precipitation in a wide range of environments [5].

\subsection{Role of Bacteria in MICP Soil Treatment}

Numerous different bacterial species have previously been detected and assumed to be associated with natural carbonate precipitates from diverse environments. The primary role of bacteria in the precipitation process has subsequently been ascribed to their ability to create an alkaline environment (high $\mathrm{pH}$ ) through various physiological activities $[6,7,8]$.

The rate of microbiological $\mathrm{CaCO} 3$ precipitation correlated with cell growth and microbial rate of precipitation, Microbial Calcite Precipitation (MCP) was significantly faster than that of chemical precipitation.

\section{Materials and Method}

\subsection{Soil Sample}

The soil sample used for the research was a marginal soil obtained from BARA located at Alkaleri Local Government of Bauchi State, Nigeria. Table 1 shows the values of the physical indices of the soil specimens obtained from the standard soil property tests. Based on the unified Soil Classification System, the marginal soil was classified as Non-plastic silty sands (SMN). It has $46 \%$ of 50-400 $\mu$ m particle grains size, an ideal size range for MICP [9].

Table 1. Soil Sample - Basic Properties

\begin{tabular}{|ll|}
\hline Specific gravity & 2.65 \\
Maximum Dry Density & $1.99\left(\mathrm{mg} / \mathrm{m}^{3}\right)$ \\
Optimum Moisture Content & $8.00(\%)$ \\
Liquid Limit & $14.00(\%)$ \\
Plastic Limit & - \\
Plasticity Index & non plastic \\
\hline
\end{tabular}




\begin{tabular}{lc}
\hline Permeability & $4.42 \times 10^{-6}(\mathrm{~m} / \mathrm{s})$ \\
California Bearing Ratio & $16.00(\%)$ \\
Unconfined Compressive Strength & $24\left(\mathrm{KN} / \mathrm{m}^{2}\right)$ \\
Unified Soil Classification & $\mathrm{SMN}$
\end{tabular}

\subsection{Microorganism (Bacterial Isolate)}

For microbially induced calcite precipitation (MICP) to be effective, a microorganism must be selected that is capable of $\mathrm{CO}_{2}$ production paralleled by a $\mathrm{pH}$ rise in the surrounding environment to an alkaline level that induces precipitation of calcium carbonate. Aerobic microorganisms capable of consuming urea as an energy source are particularly good candidates because they provide two sources of $\mathrm{CO}_{2}$ respiration by the cell and decomposition of urea. Therefore, an isolate of common bacteria naturally occurring in the subsurface, which is an alkalophilic aerobic microorganism whose cells have not been aggregated, was selected.

Microorganism- the bacterial isolate was isolated from soil sample obtained from farm site; four (4) different samples were collected and were used for the isolation of the isolate. They were inoculated on Nutrient Broth, Nutrient Agar and MICP agar respectively.

\subsection{Methods}

\subsubsection{Preparation of Culture Media}

Bacterial isolate was cultivated under aerobic batch conditions in $20 \mathrm{~g} / \mathrm{l}$ yeast extract and $10 \mathrm{~g} / \mathrm{l}$ ammonium chloride . $\mathrm{pH}$ medium was adjusted to 9 by $4 \mathrm{NNaOH}$ before autoclaving and the organism was grown to late exponential/ early stationary phase before harvest and it was stored at $4{ }^{\circ} \mathrm{C}$ prior to use. Optical density and urease activity of the bacterial fluid was determined before the treatment of the soil commenced and the bacteria concentration was varied as $1 \times 10^{5} \mathrm{cfu} / \mathrm{ml}, 1 \times 10^{6} \mathrm{cfu} / \mathrm{ml}$ and $1 \times 10^{7} \mathrm{cfu} / \mathrm{ml}$. This was achieved by serial dilution with sterile saline solution $(9 \mathrm{~g} / \mathrm{l}$ of sodium chloride). 


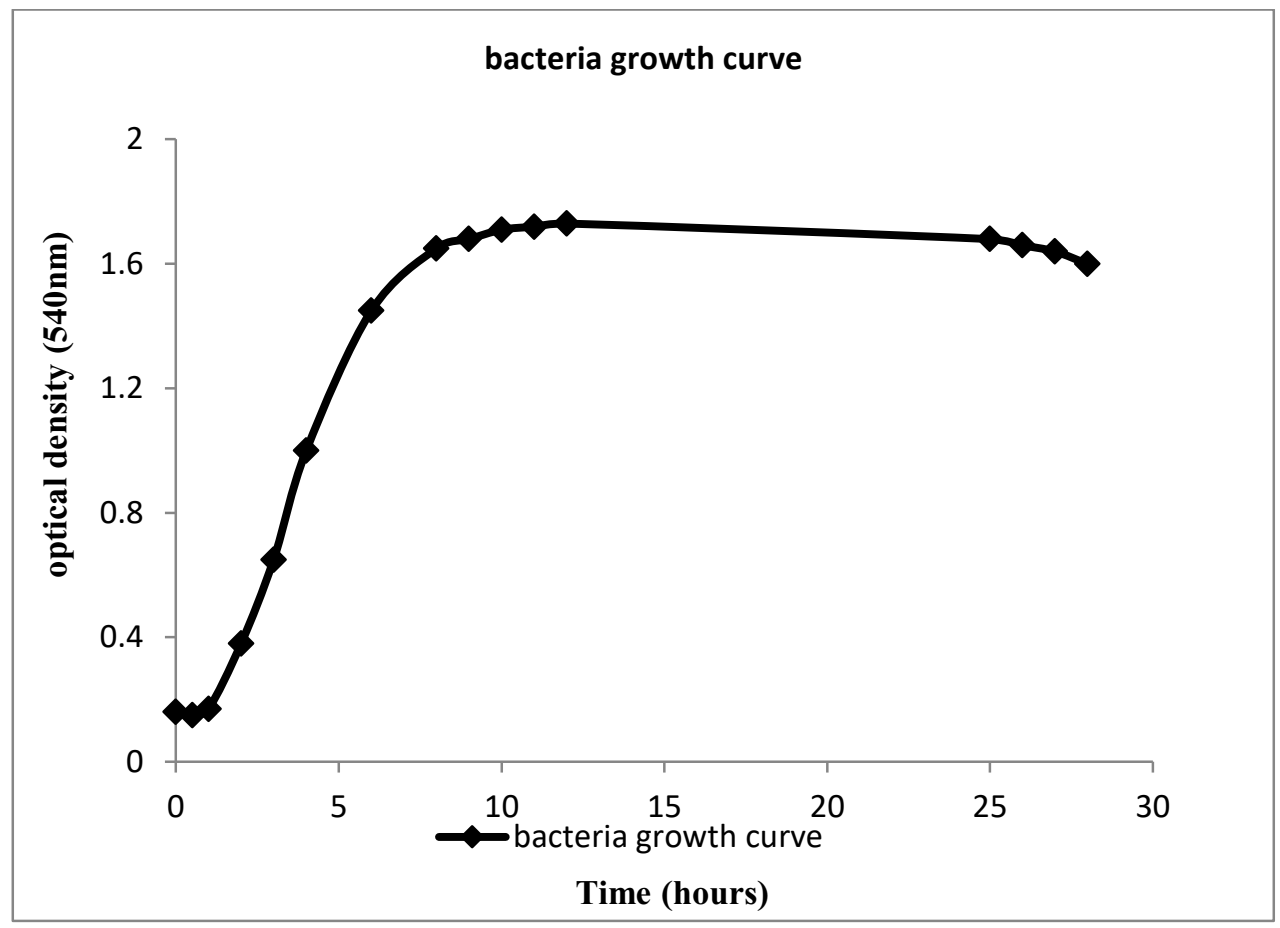

Fig. 1. Bacteria Growth Curve

\subsubsection{Cementation Reagent}

The following chemicals were added to make the cementation reagent: Urea, Calcium Chloride, and Nutrient Broth. These reagents were mixed together and dissolved in a liter of distilled water and the mixture was heat sterilized in an autoclave machine for 15 minutes at $121{ }^{\circ} \mathrm{C}$ to remove any contaminants that might contaminate the organism.

\subsubsection{Sample Preparation}

The soil materials were mixed with the prepared bacterial isolate solutions with a determined OMC for which $25 \%$ of the water content was used as the bacterial content. The soil mixtures were then compacted in the fabricated molds for CBR, Permeability and unconfined compressive strength treatments respectively. The experiment was conducted in three phase namely the retention period, the treatment period and the curing period.

\section{Results and Discussion}

\subsection{Results of Hydraulic Conductivity}

Figure 2 shows a saturated hydraulic conductivity and the calcite contents of the control soil specimens $\mathrm{C} 1, \mathrm{C} 2$ and $\mathrm{C} 3$. $\mathrm{C} 1$ is the original soil specimen. $\mathrm{C} 2$ is a soil specimen with the inclusion of isolate only with concentration $1 \times 10^{7} \mathrm{cfu} / \mathrm{ml}$, and $\mathrm{C} 3$ is a soil specimen treated with cementation reagent only $(0.5 \mathrm{M})$ for 48 hours. The untreated specimen $\mathrm{C} 1$ was used as a bench mark for compering improvement and calcite content deposition of MICP soil, 
saturated hydraulic conductivity of the control test. $\mathrm{C} 2$ reduced the hydraulic conductivity by $3.8 \times 10^{-6} \mathrm{~m} / \mathrm{s}(14 \%)$. This reduction was suggested to have been caused by the plugging of biomass in pore spaces. This indicated the effect of biomass through inclusion of isolate in soil specimen.

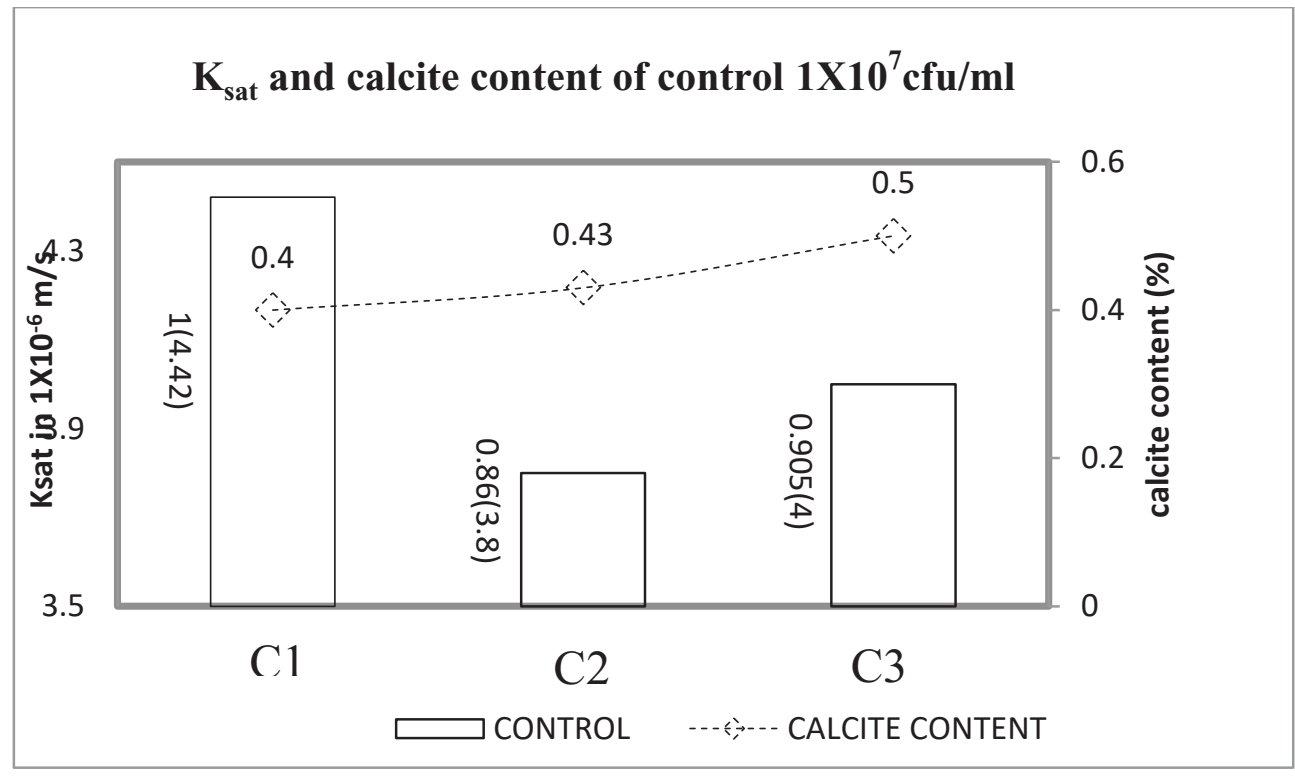

Fig. 2. $\mathrm{K}_{\text {Sat }}$ and Calcite Content of Control

The control specimen $\mathrm{C} 3$ with $0.5 \mathrm{M}$ concentration of cementation reagent which was treated for 48 hours showed a slight decrease in hydraulic conductivity of $4.0 \times 10^{-6} \mathrm{~m} / \mathrm{s}$ (9.5\%). This slight decrease was caused by the metabolic activities of indigenous bacteria that are present in the soil and the supply of calcium from the cementation reagent. The calcite content in the original marginal soil specimen $(\mathrm{C} 1)$ was $0.4 \%$. Inclusion of isolate only (C2) did not promote calcite precipitation. The slight increment of $(0.1 \%)$ in calcite content observed in the control specimen treated with cementation reagent only was negligible. This observation could be attributed to the presence of indigenous ureaseproducing bacteria in the soil.

3.2 EFFECTS OF CONCENTRATIONS OF ISOLATE $\left(1 \times 10^{5} \mathrm{cfu} / \mathrm{ml}, 1 \times 10^{6} \mathrm{cfu} / \mathrm{ml}\right.$, AND $\left.1 \times 10^{7} \mathrm{cfu} / \mathrm{ml}\right)$ AND REAGENT (0.1 M, $0.25 \mathrm{M}, 0.5 \mathrm{M}$, AND $\left.0.75 \mathrm{M}\right)$ ON SATURATED HYDRAULIC CONDUCTIVITY (KSAT) AND CALCITE CONTENT OF MICP-TREATED MARGINAL SOIL SPECIMENS

From figures 3, 4 and 5 showing the treatment durations of 24, 48 and 72hours, it can be observed that the saturated hydraulic conductivity of the soil has reduced with an increase in cementation reagent concentration. A high reduction of bacterial concentration of $0.93 \mathrm{X}^{-}$ ${ }^{6} \mathrm{~m} / \mathrm{s}(78.9 \%)$ was noticed with $0.75 \mathrm{M}$ and a high amount of $1 \mathrm{X}^{1} 0^{7}$ of calcite precipitated $(7.81 \%)$. Meanwhile a relatively lower reduction in bacterial concentration of $4.19 \times 10^{-6} \mathrm{~m} / \mathrm{s}$ $(5.2 \%)$ was observed with relatively low calcite precipitation of $1.5 \%$. Please note that two sets of values are shown in the figures. The values in the bracket represent the permeability values and the ones outside the bracket are reduction ratios in relation to the control. 


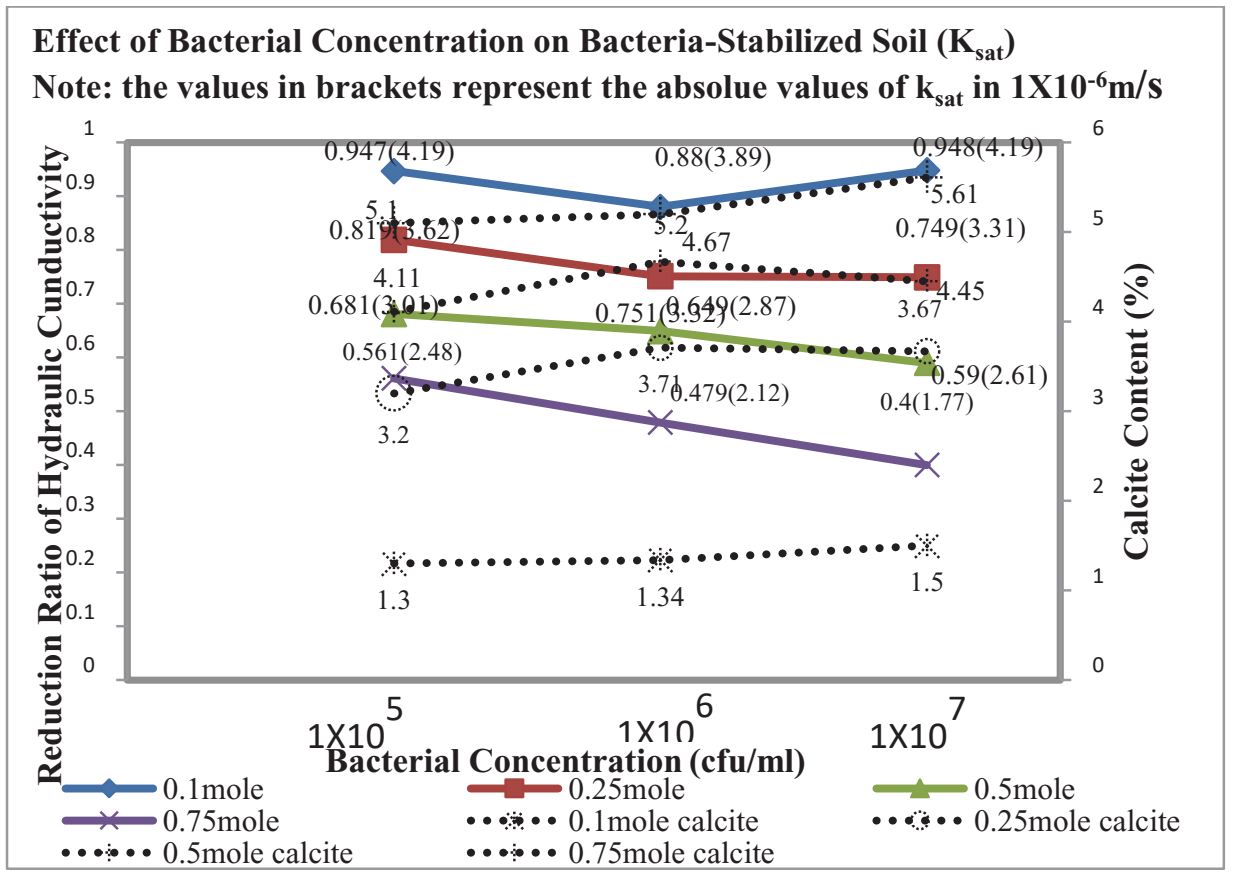

Fig. 3. 24 Hours Treatment Duration

Effect of Bacterial Concentration Bacteria-Stabilized Soil

Note: the values in brackets represent the absolue values of $\mathrm{k}_{\mathrm{sat}}$ in $1 \times 10^{-6} \mathrm{~m} / \mathrm{s}$

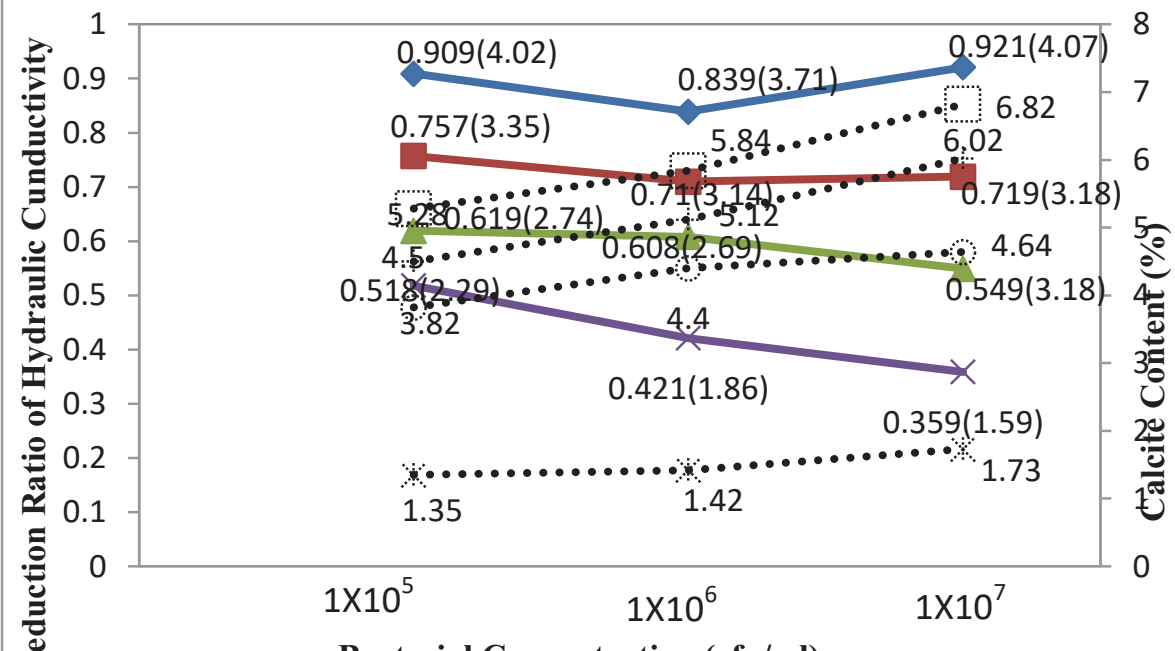

Bacterial Concentration (cfu/ml)

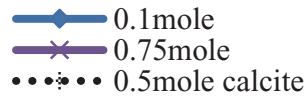

$\begin{array}{ll} & 0.25 \text { mole } \\ \cdots \cdots & 0.1 \text { mole calcite } \\ \cdots & 0.75 \text { mole calcite }\end{array}$

$-0.5 \mathrm{~mole}$

... 0.25 mole calcite

Fig. 4. 48 Hours Treatment Duration 


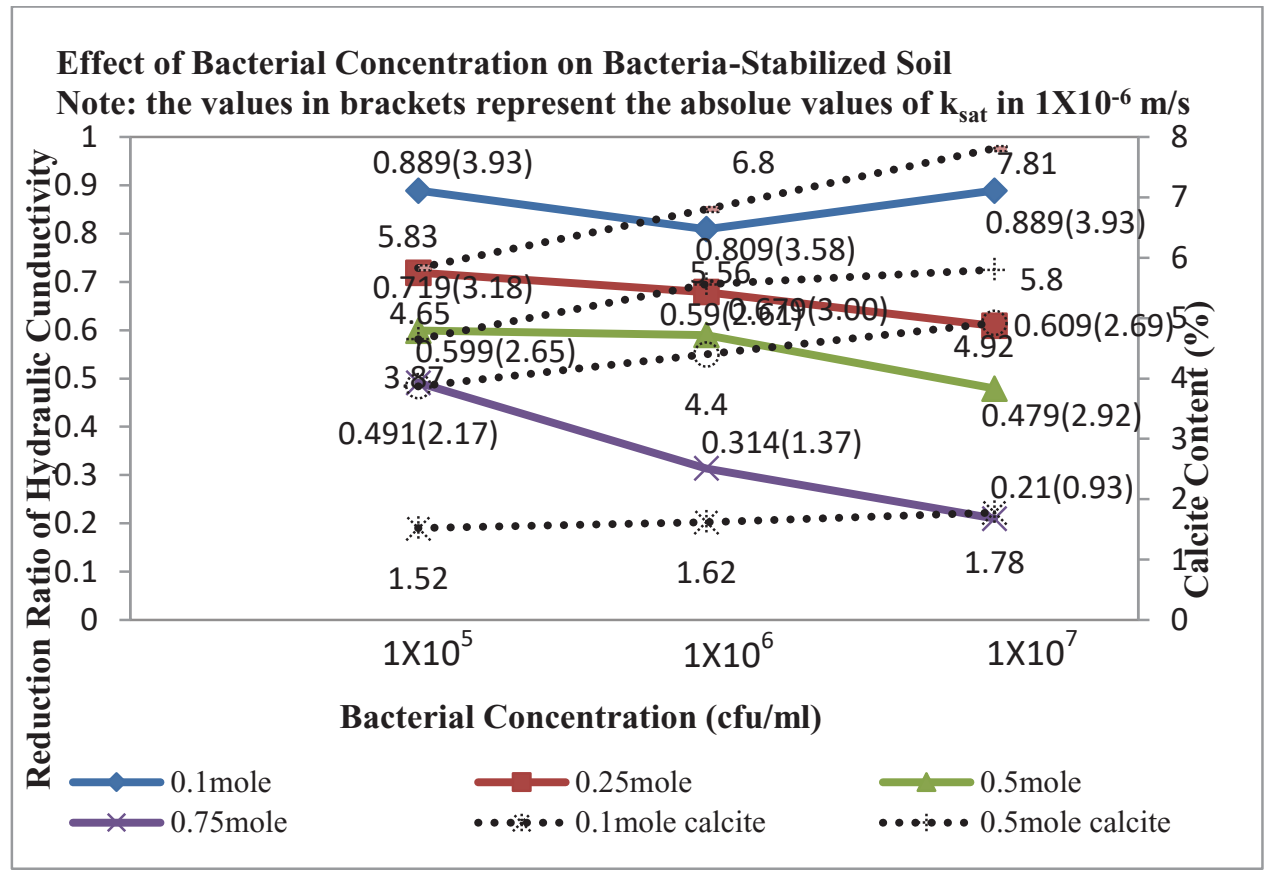

Fig. 5. 72 Hours Treatment Duration

\subsection{Result of California Bearing Ratio}

The California Bearing Ratio (CBR) values of the control specimens are presented in fig. 6 . The $\mathrm{CBR}$ value of $\mathrm{C} 1$ which was the original $\mathrm{CBR}$ of the soil was to enable comparison with the treated soil specimens. $\mathrm{C} 2$ was the soil specimen treated with inclusion of bacteria only to monitor the presence of biomass on the treated soil and the value was found to reduce slightly to $15.8 \%(2 \%)$. This reduction may be caused by the presence of bacteria inhibiting the soil. $\mathrm{C} 3$, which is the soil treated with cementation reagent only, slightly improved to $16.15 \%(0.94 \%)$. This is negligible and can be attributed to the presence of indigenous bacteria in the soil. The calcite content showed a slight improvement of $0.3 \%$ for both $\mathrm{C} 2$ and $\mathrm{C} 3$ compared to the control. 


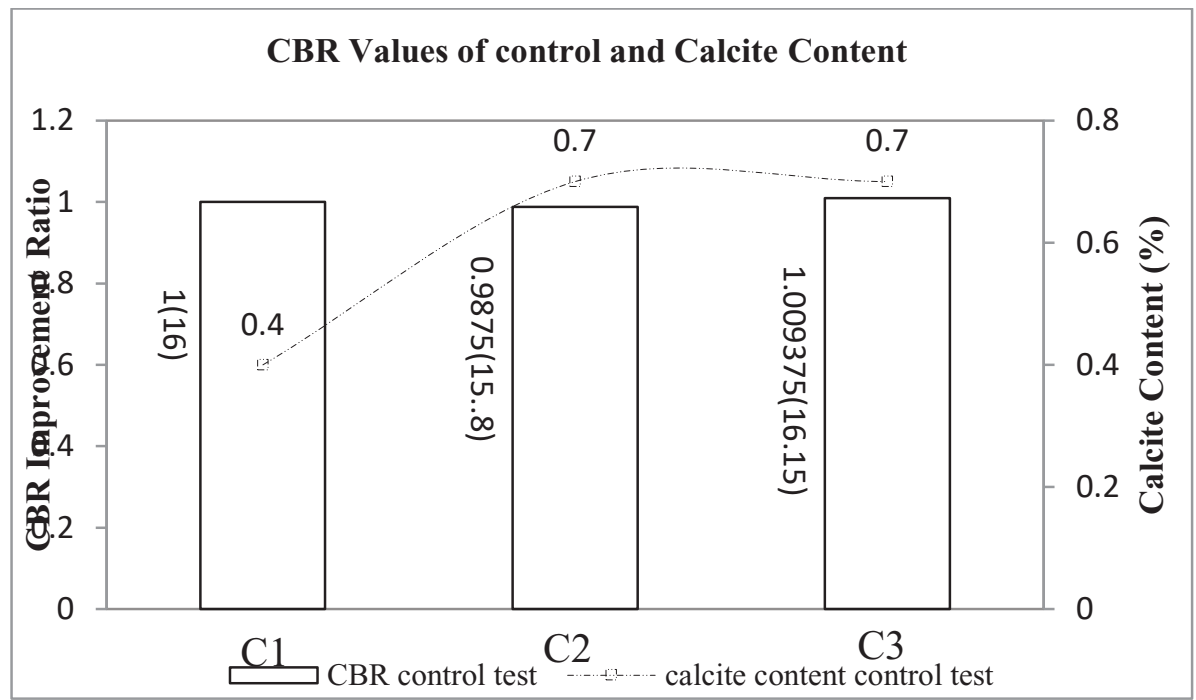

Fig. 6. CBR Values of Control and Calcite Content

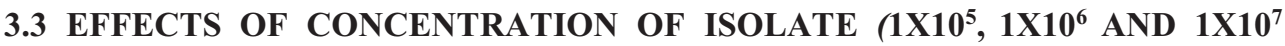 $\mathrm{cfu} / \mathrm{ml}$ ) AND CEMENTATION REAGENT (0.1M, 0.25M, 0.5M AND 0.74M) ON THE CBR AND CALCITE CONTENT OF MICP TREATED MARGINAL SOIL}

Figures 7, 8 and 9 show the CBR results corresponding to 24, 48 and 72 hours treatment durations respectively. The CBR values can be noticed to increase with an increase in cementation reagent and bacterial concentration for all the treatment periods considered. The figures also indicate that there is a linear relationship between the calcite content and increase in strength of the marginal soil. Please note that two sets of values are shown in the figures. The values in the bracket represent the actual CBR values and the ones outside the bracket are improvement ratios. 


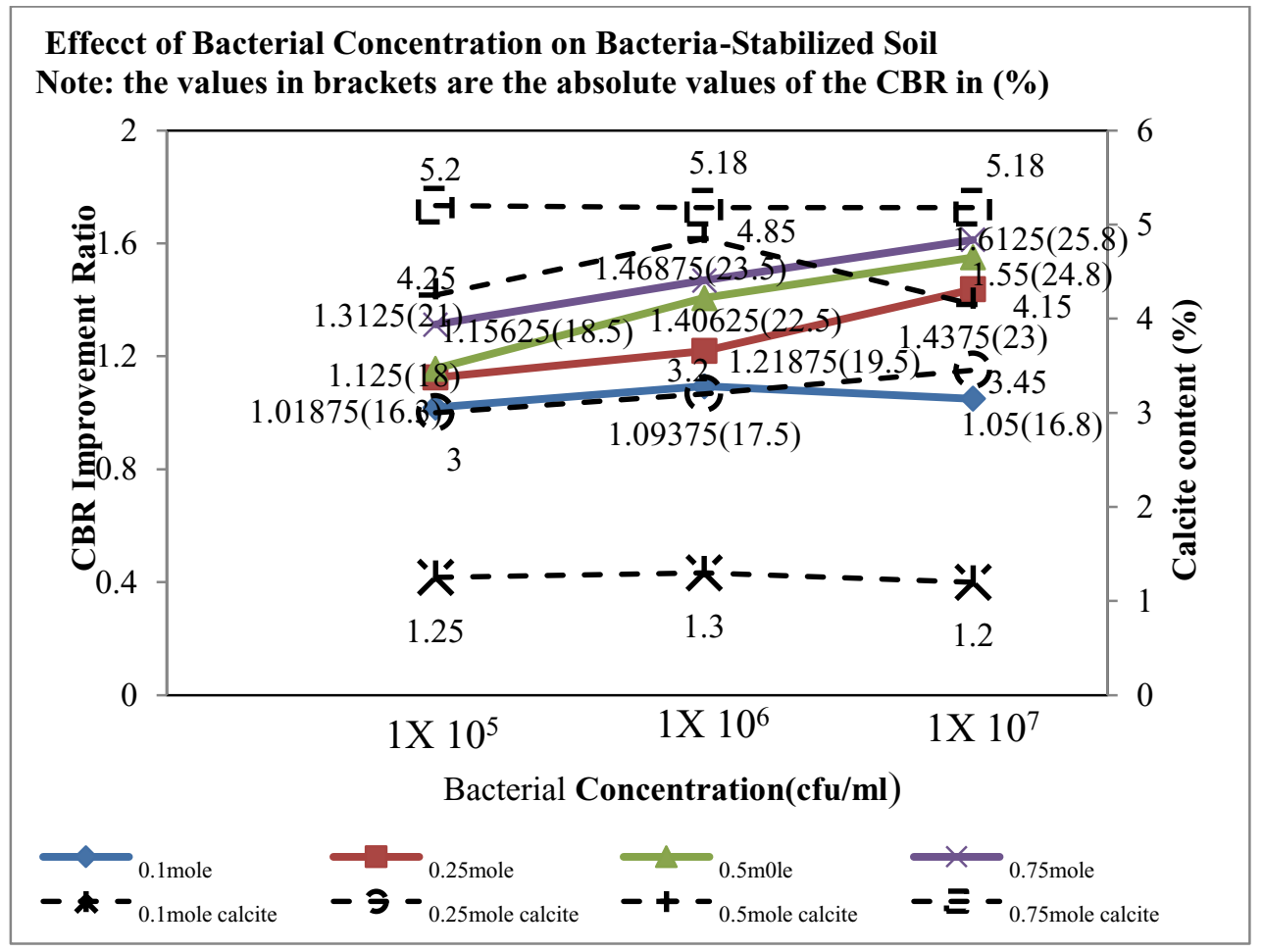

Fig. 7. 24 Hours Treatment Duration 


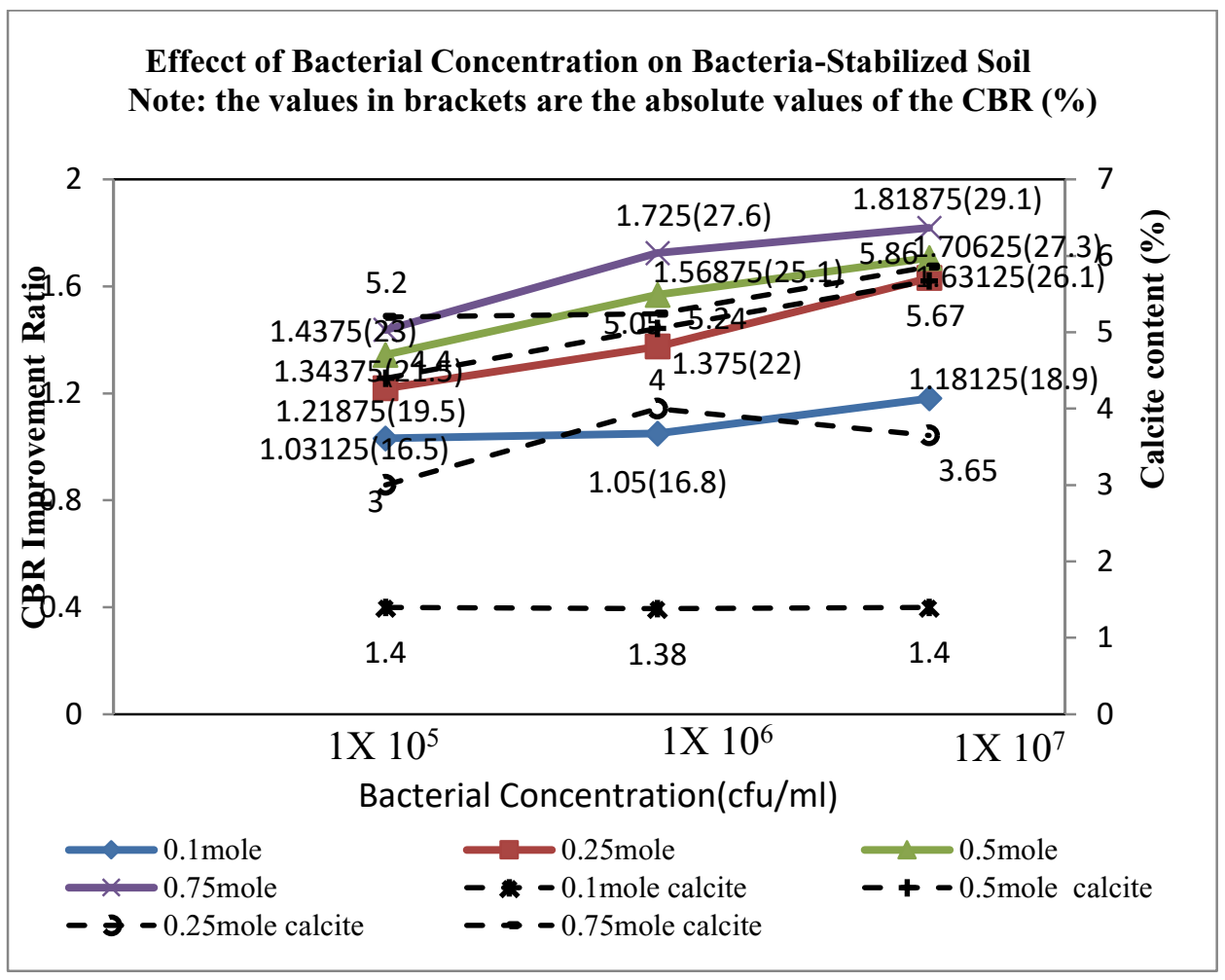

Fig. 8. 48 Hours Treatment Duration

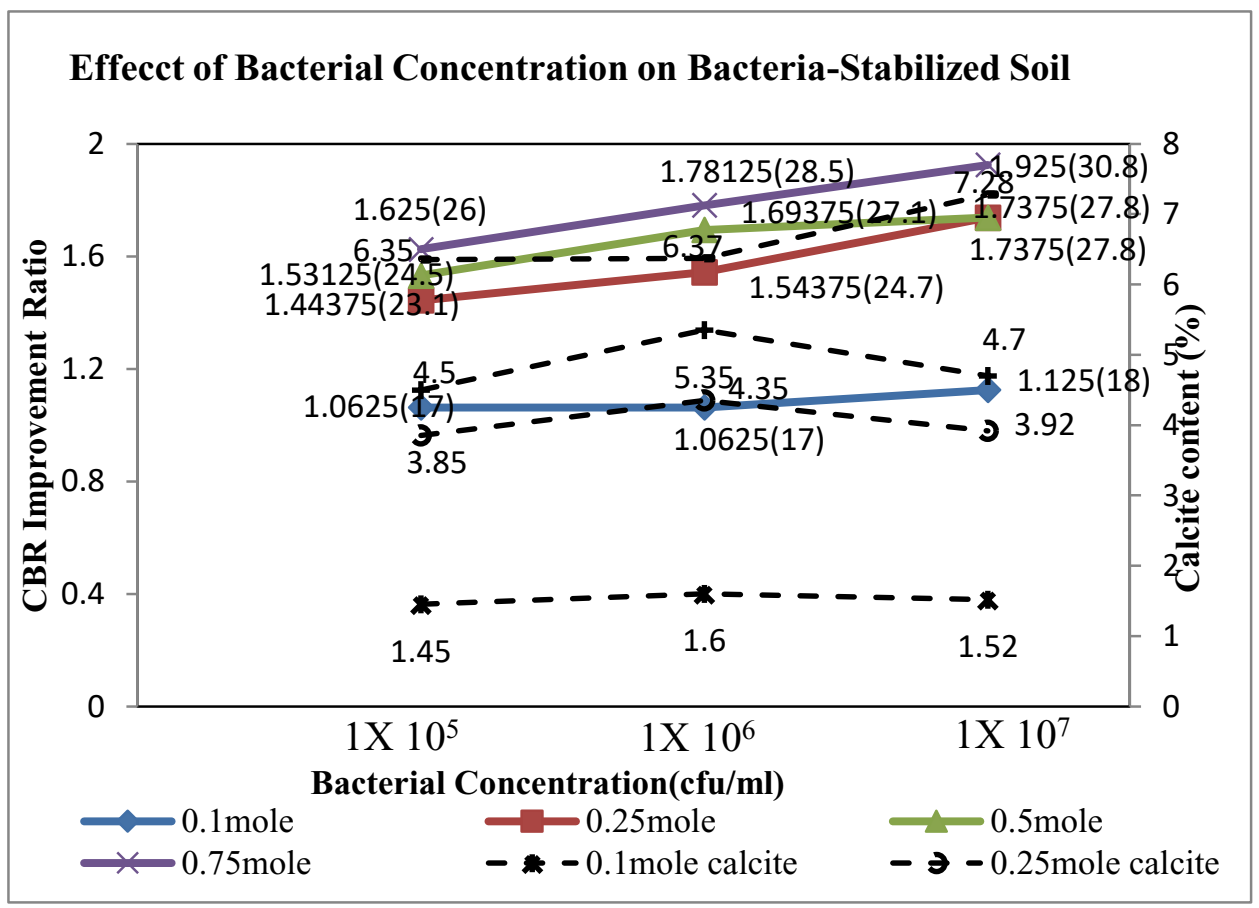

Fig. 9. 72 Hours Treatment Duration 


\subsection{Result of Unconfined Compressive Strength (UCS)}

Figure 10 shows the UCS values and the calcite content of the control specimen C1. C2, the specimen treated with the inclusion of bacterial concentration of $1 \times 10^{7} \mathrm{cfu} / \mathrm{ml}$ only and $\mathrm{C} 3$, the specimen treated with the inclusion of cementation reagent of $0.5 \mathrm{M}$ only were treated for 48h. The UCS of C2 decreased slightly to $23.2 \mathrm{KN} / \mathrm{m}^{2}(3.33 \%)$.

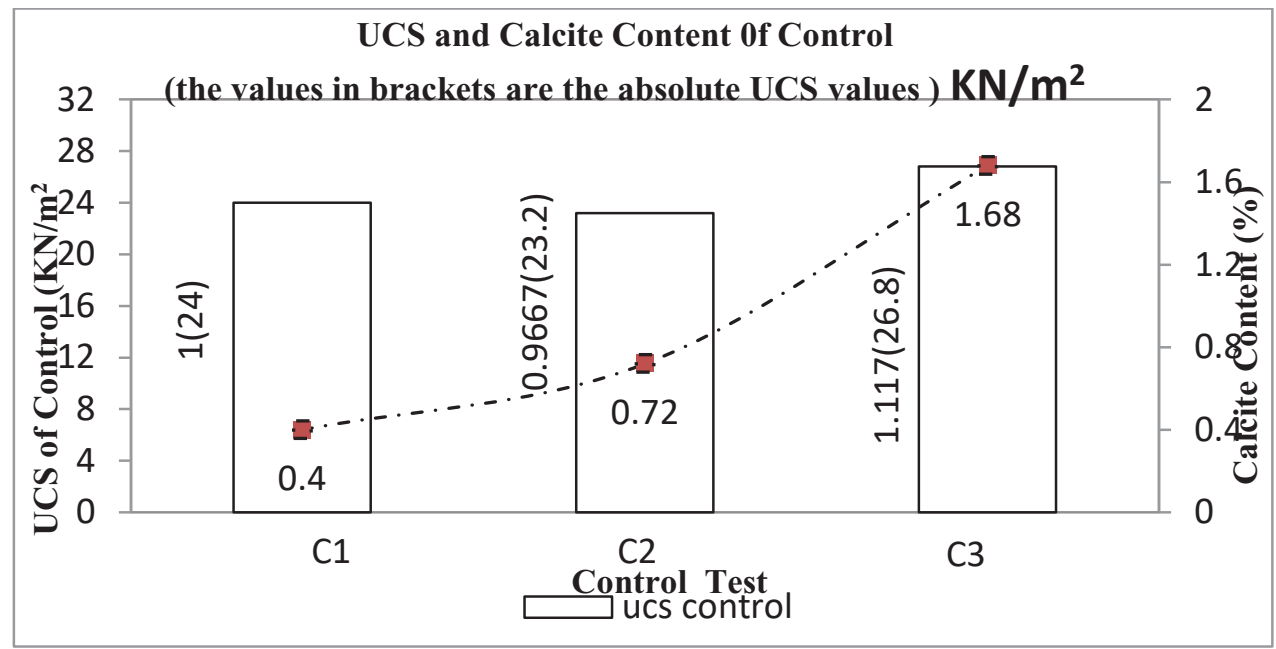

Fig. 10. UCS Values and Calcite Content of Control

This decrease might have been caused by inhibition of the bacteria due to biomass effect and the UCS of C3 was observed to increase to $26.8 \mathrm{KN} / \mathrm{m}^{2}(17 \%)$. This increase might have been caused by metabolic activities of the indigenous bacteria that are presence in the soil. For the calcite content, an improvement of $0.32 \%$ and $1.28 \%$ were observed for $\mathrm{C} 2$ and $\mathrm{C} 3$ respectively.

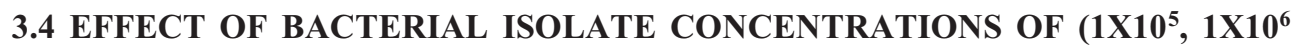

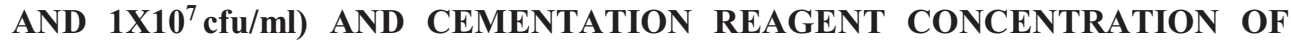
0.1M, 0.25M, 0.5M AND 0.75M ON THE UCS AND CALCITE CONTENT OF BACTERIA STABILIZED SOIL (MICP)

Figures 11, 12 and 13 show the UCS values corresponding to 24, 48 and 72 hours treatment durations respectively. 


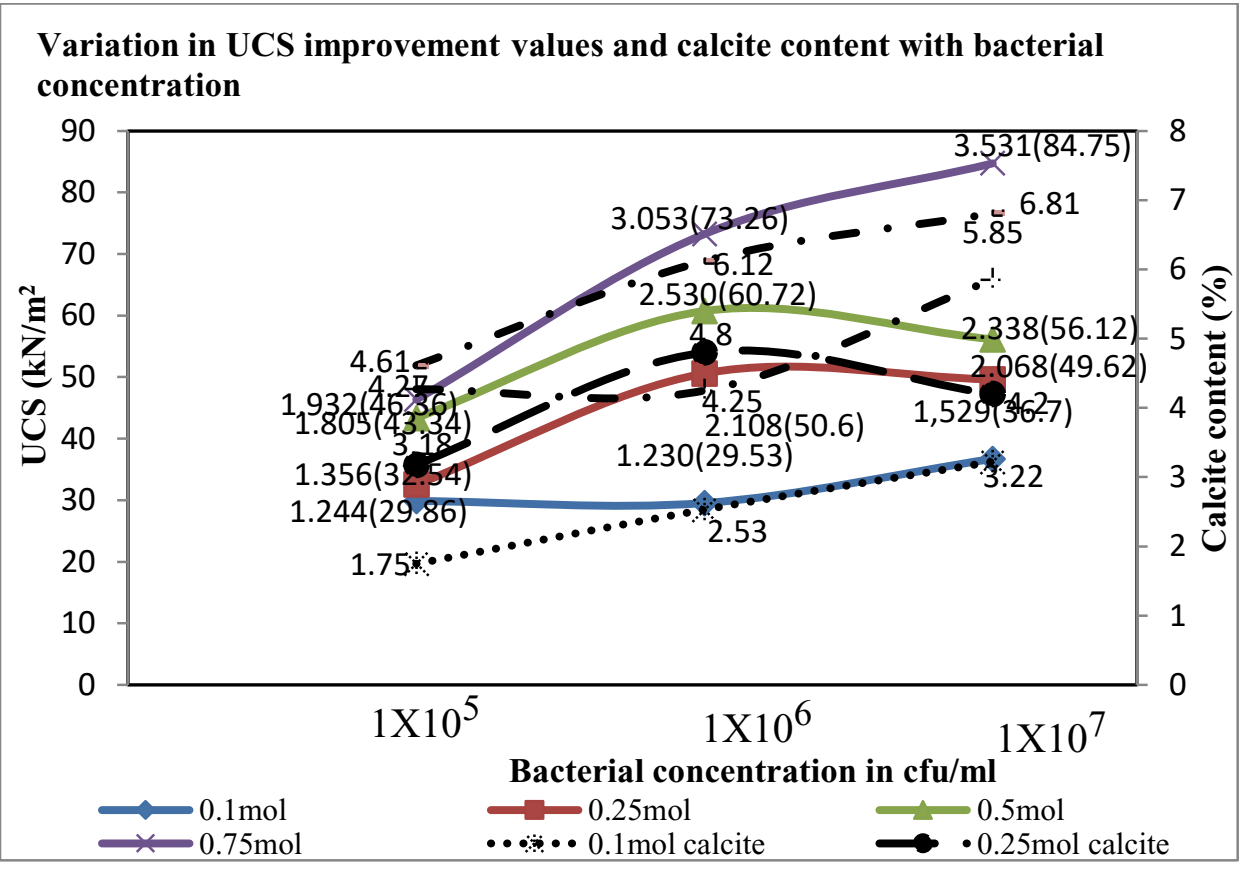

Fig. 11. 24 Hours Treatment Duration

The UCS was observed to increase with an increase in cementation reagent and bacterial concentrations. The calcite content was also observed to increase in a similar manner. Please note that two sets of values are shown in the figures. The values in the bracket represent the actual measured UCS values and the ones outside the bracket are improvement ratios.

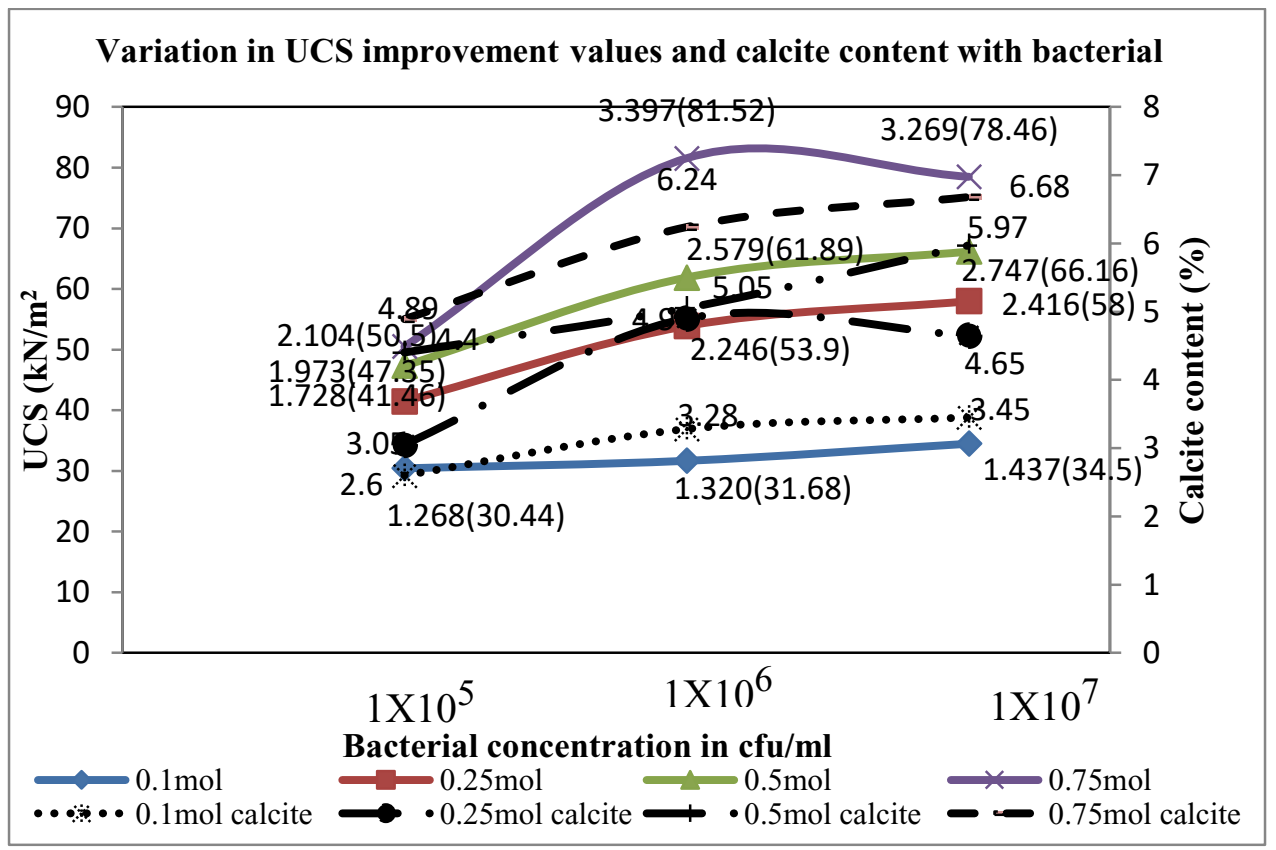

Fig. 12. 48 Hours Treatment Duration 


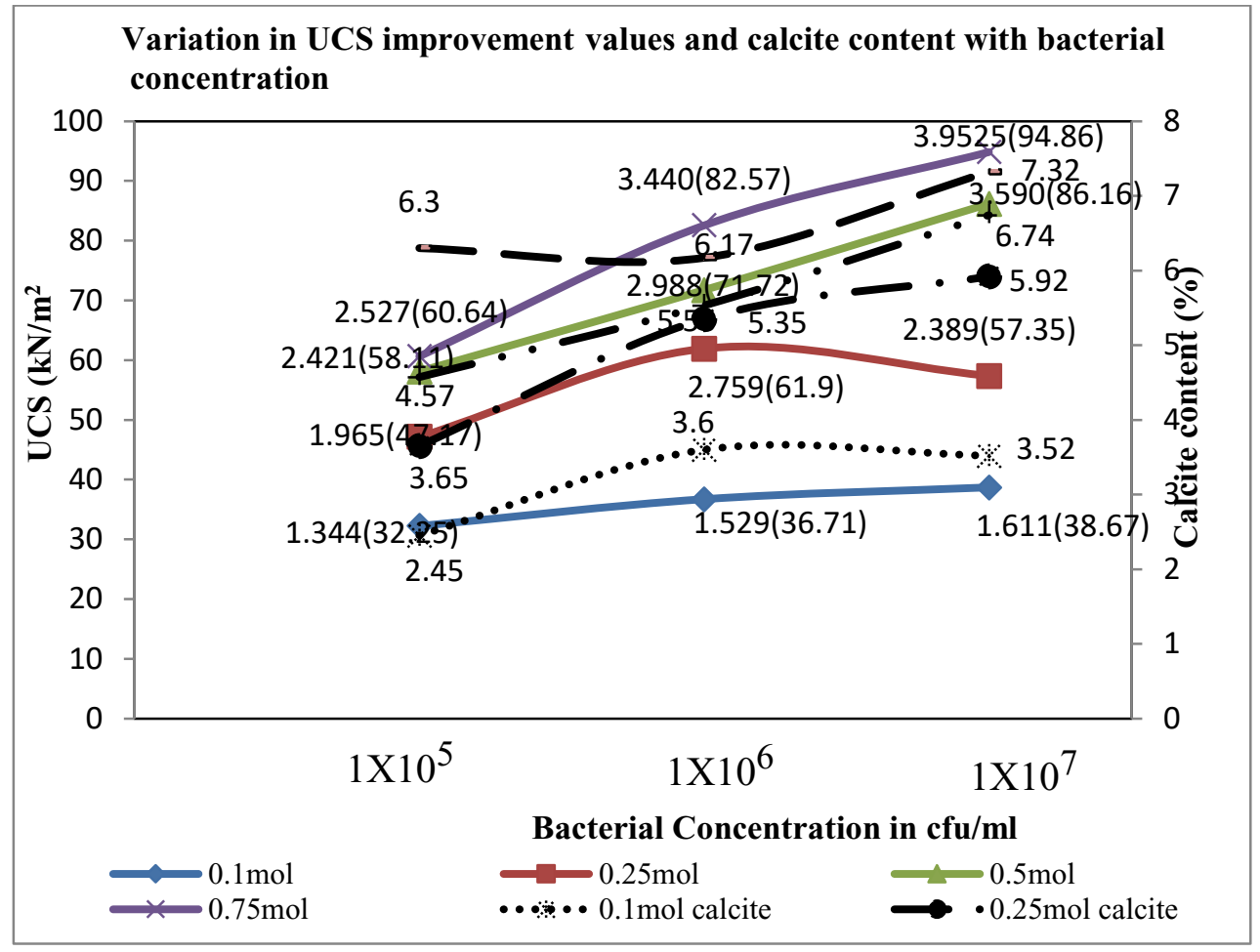

Fig. 13. 72 Hours Treatment Duration

\subsection{Discussion}

Microbial induced calcite precipitation has been shown to be an effective method to enhance the shear strength and reduce hydraulic conductivity of marginal soil. The soil with enhanced strength can contribute to a greater ground bearing capacity, while reduced hydraulic conductivity can minimize settlement, shrink-swell tendency, seepage, and infiltration of rainfall into soils. [10]. Potential application of MICP as a soil improvement technique.

From the results of the experimental tests presented in this study, there was a significant alteration in the mechanical properties of the studied soil specimens treated with MICP as compared with the control tests. The alteration was either of increase or decrease for all the mechanical properties of the soil considered. The improvement was due to the biochemical reaction that took place via the metabolic activities of the isolate and the supply of cementa tion reagent. The treatment also showed slight improvement in engineering properties of $\mathrm{C} 2$ and $\mathrm{C} 3$ compared with the control $\mathrm{C} 1$. This improvement was believed to have been caused by the biomass effect of the isolate and the presence of indigenous bacteria couple with the supply of cementation reagent. The improvement in the mechanical properties of the MICP treated soil was observed to increase with increasing concentration of the bacteria and increasing concentration of cementation reagent. The improvement was also noticed to be directly related to the treatment durations. These results were corroborated by a study carried out by [11]. 


\section{Conclusion}

From the biochemical tests of the isolates and the experimental tests conducted to investigate the effectiveness of the isolates on microbial induced calcite precipitation (MICP) in improving the engineering properties of marginal soil, the following conclusions were drawn:

1. The collected soil was found to be a suitable material for MICP soil treatment having $46 \% 40$ - $500 \mu \mathrm{m}$ particle grain size.

2. The isolated organism was capable of producing metabolic activities and can perform urease production which is responsible for urea hydrolysis. This was used in demonstrating the enhancement in the shear strength and CBR, and a reduction in hydraulic conductivity of marginal soil studied.

3. The improvement in the engineering properties of the marginal soil was directly related to the increase in calcite content.

4. The preference conditions for MICP treatment of the marginal soil was obtained at higher concentrations of the cementation reagent $(0.75 \mathrm{~mole})$ and of the isolate $\left(1 \mathrm{X} 10^{7} \mathrm{cfu} / \mathrm{ml}\right)$ at the maximum treatment duration of 72 hours.

\section{Recommendation}

Stabilization of soil with bacteria is an eco-friendly and effective method of stabilization and would serve as an oil stabilization method to replace chemical stabilization which is harmful to the environment. Based on the analysis of the result and the findings of this study, it was recommended that the optimum bacterial concentration for effective calcite precipitation is $1 \mathrm{X} 107 \mathrm{cfu} / \mathrm{ml}$ and the optimum concentration of cementation reagent is $0.75 \mathrm{M}$.

\section{References}

[1]. I.S. Dunn, L.R. Anderson, F.W. Kiefer, Fundamentals of Geotechnical Analysis (New york, Wiley, 1980).

[2]. J. K.. Mitchell and J. C. Santamarina, Biological considerations in geotechnical. J. Geotechn. Geoenviron. Eng., 131, 1222-1233. (2005).

[3]. Army Corps of Engineers, Soil Stabilization for Pavements. Joint Departments of the Army and Air Force, Washington, DC. (1994).

[4]. NRC, Geological and Geotechnical Engineering in the New Millennium (Washington, DC.: National Academies Press, 2006).

[5]. N. K. Dhami, S. Sudhakara Reddy, A. Mukherjee, Biomineralization of calcium carbonate sand their engineered applications:. a review. Frontiers in Microbiology 04 (2013).

[6]. S. Douglas and T. J. Beveridge, Mineral formation by bacteria in natural microbial communities. FEMS Microbiol.Ecol., 26,79-88, (1998), DOI: 10.1111/j.1574-6941

[7]. S. Castanier, G. Le Metayer-Levrel, J. P. Perthuisot, Bacterial roles in the precipitation of carbonate minerals. In: Riding RE, Awramik SM, editors. Microbial sediments.Springer-Verlag; (2000).

[8]. Y. Fujita, F. G. Ferris, R. D. Lawson, F. S. Colwell, R. W. Smith, Calcium carbonate precipitation by ureolytic subsurface bacteria Geomicrobiol.J, 17, 305318, (2000), DOI: 10.1080/782198884

[9]. V. Rebata-Landa, Microbial Activity in Sediments: Effects on Soil Behavior, Ph.D. Dissertation, School of Civil and Environmental Engineering, Georgia Institute of Technology, Atlanta, GA (2007). 
[10]. V. S. Whiffin, L. A. vanPaassen, M. P. Harkes, Microbial carbonate precipitation as a soil improvement technique, Geo. microbio. Journal, 24, 5 (2007).

[11]. A. R. R. Sharma, Study on effect of Microbial Induced Calcite Precipitates on strength of fine grained soils, Perspectives in Science 08 (2016) 